\title{
Az alvási apnoe szindróma vezetó rizikótényezőinek esélyhányadosai
}

\author{
Szabó Krisztina ${ }^{1}$ - Ihász Ferenc dr. ${ }^{2}$ \\ ${ }^{1}$ Sümegi Járóbeteg Szakellátó Központ, Sümeg \\ ${ }^{2}$ Széchenyi István Egyetem, Egészség- és Sporttudományi Kar, Győr
}

\begin{abstract}
Bevezetés: Az alvás minősége komoly szerepet játszik az egyén nappali teljesítőképességében és egészségi állapotában, erős hatást gyakorolva ezáltal a társadalomra.

Célkitüzés: Jelen vizsgálat a légzészavarok csoportjába tartozó obsruktív alvási apnoe szindróma kialakulásának és súlyosságának valószínúségét méri, a kórkép vezető rizikótényezőinek esélyhányadosain keresztül.

Módszer: A vizsgálatban 127 fó vett részt. Az alvásszerkezet vizsgálatához poliszomnográfiás szưrőkészülék adatai kerültek feldolgozásra. A tápláltság mértéke testtömegindexben, a nyakkörfogat adatai cm-ben kerültek rögzítésre. Eredmények: A nem mint rizikótényező vizsgálata alapján elmondható, hogy a férfiak esélyhányadosa a nőkéhez viszonyítva az alvási apnoe szindróma kialakulására több mint háromszoros. A súlyos kórkép kialakulására több mint négyszer esélyesebbek. A vizsgált férfiak csoportjában a rizikótényezők esélyhányadosai közül a nyakkörfogat a legjelentősebb prediktora az obstruktív alvási apnoénak. A női csoport vezető esélyhányadosa a BMI.

Következtetések: Az apnoés betegek több mint 50\%-a nem számol be nappali aluszékonyságról, ami felhívja a figyelmet a rizikótényezők esélyhányadosainak szelekcióban betöltött szerepére.

Orv Hetil. 2017; 158(21): 823-828.
\end{abstract}

Kulcsszavak: obstruktív alvási apnoe, rizikófaktor, esélyhányados

\section{The probability of obstructive sleep apnea disorders emergence by odds ratio of main risk factors}

Introduction: The quality of sleep plays a serious role in the individual's daytime performace and state of health, there by it has a strong influence on the society.

Aim: The present study measures the probability developing and severity of obstructive sleep apnea syndrome, - which belongs to group of disorders of the respiratory - through odds ratio of leading risk factors.

Method: 127 persons were examined in the test. The sleep structure test data were processed by polysomnographic screening device.

Results: The nutritional level of body in mass index (BMI), and the neck circumferences data were recorded in $\mathrm{cm}$. On the basis of the examination the gender as a risk factor it can be said that the odds ratio for men compared to women, more than three times higher of emergence of disease.

Conclusions: Men's chance of the emergence of serious disease is more than four times higher than women's chance. In the men's test group the most significant predictor of obstructive sleep apnea amongst the risk factors is the circumference according to odds ratio. In women's group the leader odds ratio is BMI. More than $50 \%$ of test goup don't report about daytime sleepiness, and this fact draws our attention to the role of risk factors' odds ratio in selection.

Keywords: obstructive sleep apnea syndrome, risk factor, odds ratio

Szabó K, Ihász F. [The probability of obstructive sleep apnea disorders emergence by odds ratio of main risk factors]. Orv Hetil. 2017; 158(21): 823-828.

(Beérkezett: 2017. február 22.; elfogadva: 2017. április 11.) 


\section{Rövidítések}

AHI = Apnoe-Hypnoe Index; BMI = Body Mass Index; ESS = (Epworth Sleepiness Scale) Epworth Aluszékonysági Skála; nyakk = nyakkörfogat; $\mathrm{OR}=$ (odds ratio) esélyhányados; OSAS $=$ (obstructive sleep apnea syndrome $)$ obstruktív alvási apnoe szindróma

Amerikai kutatók álláspontja szerint az alvászavarok a legelhanyagoltabb népegészségügyi problémák közé tartoznak [1]. Alvásunk mennyiségi és minőségi jellemzőinek komoly hatása van egészségi állapotunkra. A cirkadián ritmus jólléthez szükséges szerepe miatt ma már az ûrhajósok számára is mesterségesen idézik elő a nappal-éjszaka váltakozásait [2]. A megzavart cirkadián ritmus és a depresszió közti kapcsolat régóta ismert, ugyanakkor egyre több adat utal arra, hogy a természetes nappal-éjszakai ritmus megváltozása számos más krónikus megbetegedéssel is szoros összefüggésben van. A cirkadián diszfunkciója immunrendszeri megbetegedésekkel, rheumatoid arthritissel, kardiometabolikus rendellenességekkel, emésztőrendszeri elváltozásokkal, cukorbetegséggel, illetve a karciogenezissel egyaránt szignifikáns összefüggést mutat. Mindemellett a cardiovascularis események előfordulásával és a véralvadással kapcsolatban is bebizonyosodott a cirkadián ritmus szerepe [3]. Nilsson és mtsai 17 éves prospektív vizsgálatukban összefüggést találtak a cardiovascularis mortalitás és az alvászavar között [4]. Az egészséges cirkadián ritmust számos exogén tényező mellett megzavarhatják még: dyssomniák, parasomniák, egyes neurológiai, mentális vagy egyéb testi betegségekhez társuló alvászavarok. Az Alvászavarok Nemzetközi Osztályozása szerint az alvási apnoe szindróma a dyssomniák csoportjába, azon belül pedig az intrinszik alvászavarok közé sorolható. Annak ellenére, hogy az alvási apnoe szindróma népegészségügyi jelentőségét számos vizsgálattal alátámasztották, diagnosztizálása és kezelése még mindig a betegellátás elhanyagolt részét képezik. Ennek egyik oka, hogy a kórkép nagyon gyakran maradhat kivizsgálás nélkül markáns tünetek hiányában. Az alvás alatt bekövetkező légzészavar-epizódokkal járó betegség komoly hatással van a nappali teljesítóképességre, alváskésztetésre, mindezeken keresztül jelentősen megnöveli a közúti és munkahelyi balesetek előfordulásának gyakoriságát. Szoros összefüggést mutat cardiovascularis, gasztroenterológiai megbetegedésekkel, diabetesszel, metabolikus szindrómával és egyes tüdőbetegségekkel. Az ischaemiás célszervkárosodások esélyét - úgymint szív-, tüdő- és agykárosodás sokszorosára növeli, ezért a myocardialis infarctus és a stroke független rizikófaktorának tekintjük. Az alvási apnoe szindrómának obstruktív és centrális formáját ismerjük. Az obstruktív megjelenési formát periodikus garatelzáródás jellemzi, míg a centrális formát a légzőközpont koordinációs hibája okozza. A kevert típusú apnoék esetében mind a légáramlás, mind a légzőmozgások leállása regisztrálható [5]. Az OSAS (obstructive sleep apnea syndrome) klinikai súlyosságának mértékét az apnoehypnoe epizódok óránkénti számának segítségével határozzuk meg. Ez alapján a mérsékelt súlyosságú kórkép esetén a légzészavar-epizódok száma óránként 5-15. Közepes súlyosságú OSAS-ról beszélünk, ha az ApnoeHypnoe Index óránkénti száma 15-30 közötti. Súlyos kórkép fennállása esetén óránként 30 vagy a feletti légzészavar-epizód jelentkezik [6]. Az OSAS kialakulását több rizikótényező fennállása előidézheti. Számos kutatásban igazolták az obesitas és az apnoe közötti szoros korrelációt. Kaukázusi csoporton végzett felmérések szerint a kóros tápláltsági mutató négyszeresére emeli a kórkép kialakulásának valószínúségét. Ez különösen a 40 feletti BMI-vel rendelkező személyek esetén jelentős, 40-90\% között lehet [7]. A testsúly 10\%-os emelkedése hatszorosára növelheti a közepes vagy súlyos légzészavar-epizódok számát, míg a testsúly 10\%-os csökkentésével az AHI 26\%-os csökkenése várható [8]. Newman és $m t s a i$ követéses vizsgálatukban középkorú nőket és férfiakat vizsgáltak, ahol ötven év alatt a férfiaknál 11,1\%-os, a nóknél 4,9\%-os volt a közepesen súlyos és súlyos OSAS előfordulási gyakorisága [9]. Az OSAS életkorral növekvő gyakoriságát Torzsa vizsgálta. Amíg a 40-60 éves férfiak esetében az előfordulási arány 6-8\%, addig 60 éves kor felett akár $30-40 \%$ is lehet a betegség előfordulási gyakorisága [10]. Davies és munkatársainak prospektív kutatásai alátámasztották, hogy a kóros nyakkörfogat érzékenyebb prediktora az alvási apnoe szindrómának, mint a testsúly [11]. Young és mtsai már 1997-es vizsgálatukban bizonyították az OSAS és a közúti balesetek közötti összefüggést [12]. A kezeletlen obstruktív alvási apnoe szindróma nappali alváskésztetést és aluszékonyságot okozva 5-8-szorosára növeli az elalvás miatt bekövetkező közlekedési és munkahelyi balesetek számát. A kórkép szûrésének célja az elalvásos balesetek számának csökkentése, azok megelőzése. Az erre vonatkozó módszertani ajánlást a Magyar Alvásdiagnosztikai és Terápiás Társaság hazai viszonyokhoz illesztetten alkotta meg [13]. Az OSAS előfordulási gyakorisága egyebekben szoros összefüggést mutat a dohányzással [7]. A kórkép kialakulásában jelentős szerepet játszanak bizonyos anatómiai eltérések [14]. A hormonális tényezők hatását a kórkép kialakulásának esélyére Reutrakul és $m t$ sai vizsgálták egészséges várandós és nem várandós nőkön. Adataik szerint a várandós nők AHI-ja szignifikánsan magasabb a nem várandós nókéhez képest [15]. Vizsgálatunk az obstruktív alvási apnoe kialakulásának, illetve a kórkép súlyosságának valószínúségét tárja fel a vezető rizikótényezőinek esélyhányadosain keresztül.

\section{Célkitüzés}

Vizsgálatunk célul tűzte ki az obstruktív alvási apnoe szindróma hajlamosító tényezőinek elemzését azok esélyhányadosain keresztül (életkor, nem, nyakkörfogat, BMI). 


\section{Módszer}

A vizsgálatban ( $\mathrm{n}=127$ személy) 90 férfi és 37 nő adatait elemeztük. A bevont személyek egyágyas kórteremben, tüdőgyógyászati osztályon, poliszomnográfiás technikus felügyelete mellett töltötték az éjszakát. A vizsgált személyeket háziorvosuk utalta be alvásdiagnosztikai szűrővizsgálatra az általuk vagy családtagjuk által megélt horkolás miatt. Az alvásszerkezet vizsgálatához a poliszomnográfiás szürőkészülék adatai kerültek feldolgozásra. Az alvásdiagnosztikai szűrőkészülék által rögzített adatok közül az Apnoe-Hypnoe Indexet (AHI) vizsgáltuk, amely az alvás ideje alatt bekövetkező részleges (hypnoe) vagy teljes (apnoe) garatelzáródás következtében létrejövő légzészavar-epizódok óránkénti számát jelenti. A tápláltság mértékét testtömegindexszel (BMI), a nyakkörfogat adatait cm-ben adtuk meg. A nemet, illetve életkort mint a kórkép rizikófaktorait szintén vizsgáltuk. A nappali aluszékonyságra és az alvás minőségére vonatkozó adatgyűjtés validált kérdőív segítségével, Epworth Aluszékonysági Skálával (Epworth Sleepiness
Scale - ESS; Johns 1991) történt. Az önkitöltős nappali aluszékonysági teszt maximális pontszáma 24 pont, amely a legsúlyosabb nappali alváskésztetést jelöli, 15 pont feletti értékeket súlyos nappali alváskésztetésként kell értékelni. Azoknak az egyéneknek, akik a nappali aluszékonyságot szubjektíve nem élik meg, ESS-pontszámuk 10 alatti. A rizikótényezők kórképet befolyásoló hatásait log. regressziós módszerrel kontingenciatáblázatban, esélyhányados kiszámításával szemléltetjük.

\section{Eredmények}

A nem mint rizikótényező vizsgálata alapján az OSAS kialakulására a férfiak több mint háromszor esélyesebbek a női csoporthoz képest. A súlyos alvási apnoe kialakulására a férfiaknak több mint négyszeres esélye van (1. táblázat). A férfiak rizikótényezőinek elemzése során a kóros nyakkörfogat mint vezető esélyhányados játszik szerepet a kórkép kialakulásában, több mint hétszeresére növelve az OSAS kialakulásának esélyét. A súlyos alvási

1. táblázat | Férfiak és nók esélyhányadosai az alvási apnoe kialakulására

\begin{tabular}{lllc}
\hline Csoport & Nö & Ffi & Összesen \\
\hline AHI $<5$ & 12 & 11 & 23 \\
\hline $5<=$ AHI & 25 & 79 & 104 \\
\hline & 37 & 90 & 127 \\
\hline & 2,08 & 7,1 & \\
\hline & & & \\
\hline
\end{tabular}

\begin{tabular}{lccc}
\hline Csoport & Nö & Férfi & Összesen \\
\hline $\mathrm{AHI}<5$ & 12 & 11 & 23 \\
\hline $30<=\mathrm{AHI}$ & 10 & 44 & 54 \\
\hline & 22 & 55 & 77 \\
\hline 0,8 & 4 & \\
\hline & & & \\
\hline & $\mathrm{OR}=$ & 4,8 &
\end{tabular}

AHI = Apnoe-Hypnoe Index; OR = (odds ratio $)$ esélyhányados

2. táblázat | Férfiak vizsgált rizikótényezőinek esélyhányadosai az alvási apnoe kialakulására

\begin{tabular}{|c|c|c|c|}
\hline Csoport & $\mathrm{BMI}<25$ & $\mathrm{BMI}>=25$ & Összesen \\
\hline $\mathrm{AHI}<5$ & 1 & 10 & 11 \\
\hline \multirow[t]{4}{*}{$5<=\mathrm{AHI}$} & 3 & 76 & 79 \\
\hline & 4 & 86 & 90 \\
\hline & 3 & 7,6 & \\
\hline & $\mathrm{OR}=$ & 2,5 & \\
\hline Csoport & $\mathrm{BMI}<25$ & $\mathrm{BMI}>=25$ & Összesen \\
\hline $\mathrm{AHI}<5$ & 1 & 10 & 11 \\
\hline \multirow[t]{4}{*}{$30<=\mathrm{AHI}$} & 2 & 42 & 44 \\
\hline & 3 & 52 & 55 \\
\hline & 2 & 4,2 & \\
\hline & $\mathrm{OR}=$ & 2,1 & \\
\hline
\end{tabular}

\begin{tabular}{|c|c|c|c|}
\hline Csoport & kor $<55$ & kor $>=55$ & Összesen \\
\hline $\mathrm{AHI}<5$ & 6 & 5 & 11 \\
\hline \multirow[t]{4}{*}{$5<=\mathrm{AHI}$} & 38 & 41 & 79 \\
\hline & & & 90 \\
\hline & 6,3 & 8,2 & \\
\hline & $\mathrm{OR}=$ & 1,3 & \\
\hline Csoport & kor $<55$ & kor $>=55$ & Összesen \\
\hline $\mathrm{AHI}<5$ & 6 & 5 & 11 \\
\hline \multirow[t]{4}{*}{$30<=\mathrm{AHI}$} & 22 & 22 & 44 \\
\hline & & & 55 \\
\hline & 3,6 & 4,4 & \\
\hline & $\mathrm{OR}=$ & 1,2 & \\
\hline
\end{tabular}

\begin{tabular}{cccc}
\hline Csoport & nyakk $<43$ & nyakk $>=43$ & Összesen \\
\hline AHI $<5$ & 6 & 5 & 11 \\
\hline $5<=$ AHI & 11 & 68 & 79 \\
\hline & 17 & 73 & 90 \\
\hline & 1,8 & 13,6 & \\
\hline \multicolumn{5}{c}{ OR $=$} & 7,4 & \\
\hline Csoport & nyakk $<43$ & nyakk $>=43$ & Összesen \\
\hline AHI $<5$ & 6 & 5 & 11 \\
\hline $30<=$ AHI & 3 & 41 & 44 \\
\hline 5 & 9 & 46 & 55 \\
\hline & 0,5 & 8,2 & \\
\hline & & 16,4 & \\
\hline
\end{tabular}

AHI = Apnoe-Hypnoe Index; BMI = Body Mass Index; nyakk = nyakkörfogat; OR = (odds ratio $)$ esélyhányados 
3. táblázat |Nők vizsgált rizikótényezőinek esélyhányadosai az alvási apnoe kialakulására

\begin{tabular}{lccc}
\hline Csoport & BMI $<25$ & BMI $>=25$ & Összesen \\
\hline AHI $<5$ & 6 & 6 & 12 \\
\hline $5<=$ AHI & 3 & 22 & 25 \\
\hline & 9 & 28 & 37 \\
\hline & 0,5 & 3,6 & \\
\hline \multicolumn{5}{c}{ OR $=$} & 7,3 & \\
\hline Csoport & BMI $<25$ & BMI $>=25$ & Összesen \\
\hline AHI $<5$ & 6 & 6 & 12 \\
\hline $30<=$ AHI & 1 & 9 & 10 \\
\hline \multicolumn{5}{c}{1} & 15 & 22 \\
\hline & 0,1 & 1,5 \\
\hline \multicolumn{5}{c}{ OR $=$} & 9 &
\end{tabular}

\begin{tabular}{|c|c|c|c|}
\hline Csoport & kor $<55$ & kor $>=55$ & Összesen \\
\hline $\mathrm{AHI}<5$ & 7 & 5 & 12 \\
\hline \multirow[t]{4}{*}{$5<=$ AHI } & 5 & 20 & 25 \\
\hline & & & 37 \\
\hline & 0,71 & 4 & \\
\hline & $\mathrm{OR}=$ & 5,6 & \\
\hline Csoport & kor $<55$ & kor $>=55$ & Összesen \\
\hline $\mathrm{AHI}<5$ & 7 & 5 & 12 \\
\hline \multirow[t]{3}{*}{$30<=\mathrm{AHI}$} & 2 & 8 & 10 \\
\hline & & & 22 \\
\hline & 0,28 & 1,6 & \\
\hline & $\mathrm{OR}=$ & 5,6 & \\
\hline
\end{tabular}

\begin{tabular}{lccc}
\hline Csoport & nyakk $<41$ & nyakk $>=41$ & Összesen \\
\hline AHI $<5$ & 7 & 5 & 12 \\
\hline $5<=$ AHI & 11 & 14 & 25 \\
\hline & 18 & 19 & 37 \\
\hline \multicolumn{5}{c}{1,5} & 2,8 \\
\hline Csoport & nyakk $<41$ & nyakk $<=41$ & Összesen \\
\hline AHI $<5$ & 7 & 5 & 12 \\
\hline $30<=$ AHI & 4 & 6 & 10 \\
\hline \multicolumn{5}{c}{11,7} \\
\hline & 11 & 11 & 22 \\
\hline \multicolumn{5}{c}{1,2} \\
\hline \multicolumn{5}{c}{ OR $=$} \\
\hline
\end{tabular}

AHI = Apnoe-Hypnoe Index; BMI = Bady Mass Index; nyakk = nyakkörfogat; OR = (odds ratio) esélyhányados

4. táblázat | Nók és férfiak nappali alváskésztetését mérő kérdőív pontszámai és az alvási apnoe összefüggései

Nók

\begin{tabular}{lccc}
\hline Csoport & ESS $<10$ & ESS $>10$ & Összesen \\
\hline AHI $<5$ & 9 & 3 & 12 \\
\hline AHI $>=5$ & 14 & 11 & 25 \\
\hline Összesen & 23 & 14 & 37 \\
\hline
\end{tabular}

Férfiak

\begin{tabular}{lccc}
\hline Csoport & ESS $<10$ & ESS $>10$ & Összesen \\
\hline AHI $<5$ & 9 & 2 & 11 \\
\hline AHI $>=5$ & 50 & 29 & 79 \\
\hline Összesen & 59 & 31 & 90 \\
\hline
\end{tabular}

AHI = Apnoe-Hypnoe Index; ESS = (Epworth Sleepiness Scale $)$ Epworth Aluszékonysági Skála

apnoe kialakulására közel tizenhétszeres esélyhányadossal rendelkezik. Második helyen a BMI esélyhányadosa szerepel, amely a kórkép kialakulására, illetve annak súlyosságára is közel azonos, kétszeres eséllyel hat. Harmadik helyen a rizikótényező́k közül az életkor áll, amely az alvási apnoe kialakulásának esélyét és annak súlyosságát egyformán befolyásolja (2. táblázat). A nói csoportban a BMI-nek van vezető szerepe, több mint hétszeres esélyhányadossal növelve a kórkép kialakulását. A súlyos kórkép kialakulásának esélyét kilencszeresére növeli. Ezt követi az életkor, amely a betegség kialakulására és a súlyos kórképre egyező esélyhányadossal hajlamosít. A férfiaknál vezető kóros nyakkörfogat a női csoportban az általunk vizsgált rizikótényezők közül utolsó helyet foglalja el. Az alvási apnoe kialakulásának esélyét közel kétszeresére, súlyos kórkép esélyét alig több mint kétszeresére emeli (3. táblázat). Eredményeink alapján az obstruktív alvási apnoe szindróma kialakulására a férfiak közül a kóros nyakkörfogattal, a nők közül pedig a kóros BMI-vel rendelkezók a leginkább esélyesek (1. ábra). Az általunk vizsgált férfiak csoportjában 90 fó közül 79 fó (a kórkép súlyosságától függetlenül) szenved alvási apnoe szindrómában, közülük 29 fó jelezte a megélt nappali alu- székonyságot, 50 fö szubjektíve nem tett említést erről. A nők csoportjában a 37 fó közül 25 személy (kórkép súlyosságától függetlenül) szenved alvási apnoe szindrómában, akik közül 14 fő nem él meg nappali alváskésztetést (4. táblázat).

\section{Következtetések}

Jelentős epidemiológiai vizsgálat, a Wisconsin Sleep Cohort Study eredményei alapján a férfiaknál kétszeres gyakorisággal diagnosztizáltak OSAS-szindrómát, mint a nők körében. Vizsgálatunkban a kórkép esélyhányadosai a nemek közt szintén különbséget mutattak. A férfiak esélyhányadosa a női csoporthoz képest több mint háromszoros. A vizsgált férficsoportnál vezetô rizikótényező a kóros nyakkörfogat, amely markánsan növeli a súlyos kórkép kialakulásának esélyét. A nők esetében a kóros BMI vezet legnagyobb eséllyel az OSAS kialakulásához, amelynek férfiaknál ugyan alacsonyabb az esélyhányadosa, de esetükben is megduplázza a kórkép kialakulásának esélyét. Az obstruktív alvási apnoe fennállásának megítélésére a Magyar Alvásdiagnosztikai és Terápiás 


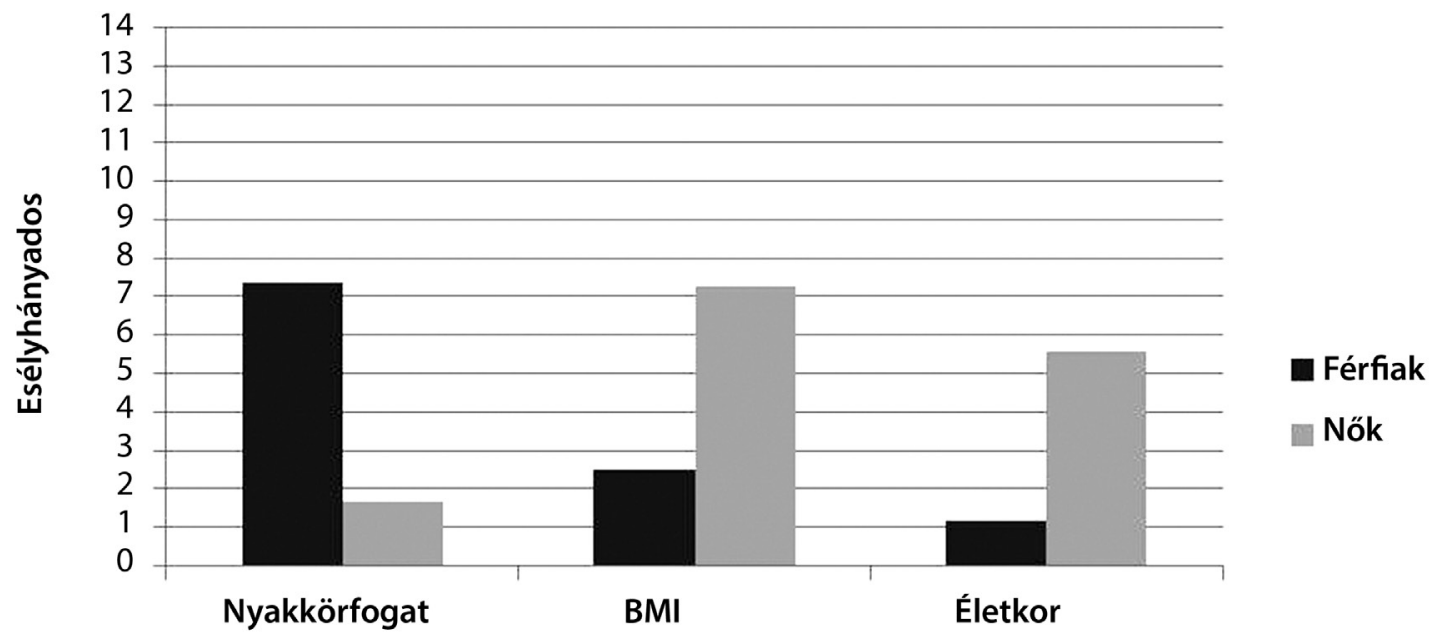

1. ábra

| Férfiak és nók rizikótényezőinek esélyhányadosai

Társaság által kidolgozott módszertani ajánlás szerint az eszközös szűrővizsgálatot előzze meg kérdőívből álló alapszürés, amelyeket a 2013-as brüsszeli OSAS-munkacsoport értekezletén hoztak létre delegált európai alvástársaságokkal konszenzusban. A kérdőívek összesített pontszáma alapján az első fokon eljáró szervnél kiderül, hogy szükséges-e további eszközös vizsgálat az obstruktív alvási apnoe szindróma diagnózisának felállításához [13]. Vizsgálatunkban bebizonyosodott, hogy a szubjektíve megélt tünetek az általunk vizsgáltak körében átlagosan több mint 50\%-ban nem hívják fel a figyelmet a kórkép fennállására. Az OSAS fennállására és a kórkép súlyosságára nézve is hasznosabb prediktor a férfiak csoportjában a kóros nyakkörfogat megléte, míg nőknél a kóros BMI. A fenti két rizikótényező mérése nem költséges, egyszerűen kivitelezhető, mindemellett csökkenti a mûszeres szûrővizsgálatra történő utalás szubjektív adatait, amelyek torzítóak lehetnek. Mai rohanó világunkban, bár egyre gyakoribbak az alvással összefüggő panaszok, a betegek döntő többsége mégis nagyon ritkán fordul pusztán ezek miatt orvoshoz. Vizsgálatunk eredményei alapján elmondható, hogy az alvási apnoe gyakran olyan tipikus tünet nélkül jelentkezik, mint a kóros nappali alváskésztetés, amelynek egyaránt jelentős következményei vannak a munkahelyi és közúti balesetek előfordulásának gyakoriságára. Mindemellett befolyásolják a teljesítőképességet és a kognitív funkciókat is. Az obstruktív alvási apnoe okozta tünetekhez a betegek hozzászokhatnak, hiszen a kórkép nem okoz egyik napról a másikra kialakuló markáns tüneteket, amely miatt a beteg az egészségügyi ellátórendszerhez fordulna. Vizsgálatunk alapján elmondható, hogy gyakran kerülhetnek olyan személyek szûrővizsgálatra, akiknél nem bizonyosodik be a kórkép fennállása. Pedig a szúrővizsgálatra történő várakozási idő a jogosítvány meghosszabbításának lehetséges időpontjára és a beteg életminőségére, továbbá betegségére, illetve annak szövődményeire is komoly hatással lehet. Fontos tehát, hogy a szubjektíve megélt tüneteken túlmenően legyen a beutaló orvos számára olyan ismert támpont, amely alapján a legnagyobb eséllyel feltételezhető a kórkép fennállása vagy akár annak súlyosságának valószínúsége is, amelyen keresztül pontosabban megítélhető a szűrővizsgálat szükségessége. Míg ha beutalási indok a horkolás, nagy valószínűséggel ez a nagy népegészségügyi jelentőséggel bíró kórkép sok esetben rejtve maradhat. Tekintettel az országban fellelhető kevés számú és igen leterhelt alváslaboratóriumok számára, az OSAS kialakulásának esélyét növelő rizikótényezők pontos ismerete nagy segítséget nyújthat a kezelőorvos számára az ellátórendszerben nehezen elérhető szűrővizsgálat szükségességének megítélése céljából. A szelekció eredményessége kiemelten fontos szempont, hiszen a szúrésre nem kerülő OSAS-betegek esetén a kórkép rejtve marad, míg számos esetben költséges, a beteg és az ellátórendszer számára egyaránt időigényes szűrővizsgálatok lennének nagyobb számban elkerülhetőek.

Anyagi támogatás: A közlemény megírása és az azt megelóző kutatómunka anyagi támogatásban nem részesült.

Szerzôi munkamegosztás: I. F.: A vizsgálat lefolytatása. Sz. K.: Statisztikai elemzések, a kézirat szövegezése. A cikk végleges változatát mindkét szerző elolvasta és jóváhagyta.

Érdekeltség: A szerzőknek nincsenek érdekeltségeik.

\section{Irodalom}

[1] National Commission on Sleep Disorders Research. Wake up America: a national sleep alert. Washington, DC. 1993.

[2] Cassone V, Steephan FK. Central and peripherial regulation of feeding and nutrition by the mammalian circadian click: Implicacions for nutrition during manned space flight. Nutrition. 2002; 18: 814-819. 
[3] Halmos T, Suba I. Physiological and pathophysiological role of the circadian clock system. [A cirkadián CLOCK-rendszer élettani és patológiai szerepe.] Orv Hetil. 2012; 153: 1370-1379. [Hungarian]

[4] Nilsson PM, Nilsson JA, Hedblad B, et al. Sleep disturbance in association with elevated pulse rate for prediction of mortality conseqences of mental strain? J Intern Med. 2001; 250: 521529.

[5] Várdi Visy K. Breathing disorsers during sleep. [Légzészavarok alvás közben.] Medicina Könyvkiadó, Budapest, 1996; pp. 1921. [Hungarian]

[6] Ádám Á, Böszörményi NG. Sleep Medicine: Sleep-wakefullness distrubances from family doctors to the sleep centers. Köves P. (ed.) [In: Alvásmedicina: alvás-ébrenléti zavarok ellátása háziorvosoktól az alváscentrumokig. Köves Péter (szerk.] Bookmaker Kiadó, Budapest, 2008; pp. 116-119. [Hungarian]

[7] Lam, JC, Sharma SK, Lam, B. Obstuctive sleep apnoea: definitions, epidemiology \& natural history. Indian J Med Res. 2010; 131: 165-170.

[8] Peppard PE, Young T, Neito FJ, et al. Longitudinal study of moderate weight chance and sleep disordered breathing. JAMA. 2000; 284: 3015-3021.

[9] Newman AB, Foster G, Givelber R, et al. Progression and regression of sleep disordered breathing with change in weight: The sleep heart health study. Arch Intern Med. 2005; 165: 24082413.

[10] Torzsa P. The obstructive sleep apnoe and the snoring clincal epidemiology and clinical significance of the family medical practice. PhD theses. [Az obstruktív alvási apnoe szindróma és a horkolás klinikai epidemiológiája és klinikai jelentősége a család- orvosi gyakorlatban. Doktori értekezés.] Semmelweis Egyetem, Mentális Egészségtudományok Doktori Iskola, 2009. [Hungarian]

[11] Davies RJ, Ali N, Stradling JR. Neck circumference and other clinical features in the diagnosis of the obstructive sleep apnoe syndrome. Thorax 1999; 47: 101-105.

[12] Young T, Blustein J, Finn L, et al. Sleep-disordered breathing and motor vechile accidents in population-based sample of employed adults. Sleep 1997; 20: 608-613.

[13] Szakács Z, Ádám Á, Annus JK, et al. Hungarian Society for Sleep Medicine guideline for detecting drivers with obstructive sleep apnea syndrome. [A Magyar Alvásdiagnosztikai és Terápiás Társaság módszertani ajánlása a közúti jármúvezetők egészségi alkalmasságának vizsgálatához az obstruktív alvási apnoe szindróma vonatkozásában.] Orv Hetil. 2016; 157: 892-900. [Hungarian]

[14] Schwab, RJ, Gubta KB, Gefter WB, et al. Upper airway and soft tissue anatomy in normal subject and patients with sleep disordered breathing. Significance of the lateral pharyngeal walls. Am J Respir Crit Care Med. 1995; 152: 1673-1689.

[15] Reutrakul S, Zaidi N, Wroblewski K, et al. Interactions between pregnancy, obstructive sleep apnea, and gestional diabetes mellitus. J Clin Endocrinol Metab. 2013; 98: 4195-4202.

(Szabó Krisztina, Tapolca, Béke u. 9/A, 8300 e-mail: krisztinaszab60@gmail.com)

\section{Ellen Notbohm-Veronica Zysk} EZEREGY NAGYSZERRIÜ ÖTLET

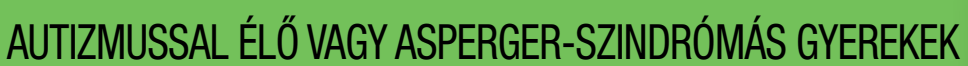
NEVELÉSÉHEZ ÉS TANÍTÁSÁHOZ

„Ha minden iskolában és családban a könyvben szereplő ötletek kis töredékét felhasználnák, beláthatatlan lehetöségek nyilinának meg elöttünk, hogy javítsuk az autizmussal vagy Asperger-szindrómával élö gyermekek életminöségét. Ez pedig csodálatos dolog!"

A könyv számtalan azonnal alkalmazható ötletet kínál szülőknek és nevelőknek az alábbi területeken:

- szenzoros integráció: fejlesztőfeladatok a szabadban és bent,

- kommunikáció: szóhasználat, hallás, vizualitás, környezet,

- viselkedés: tipikus viselkedési formák és kezelésük,

- mindennapi élet: ötletek a mindennapi szituációkhoz, a biztonság megteremtéséhez,

- szociális létezés: barátság, játék, kooperáció, érzelmek.

Dr. Temple Grandin

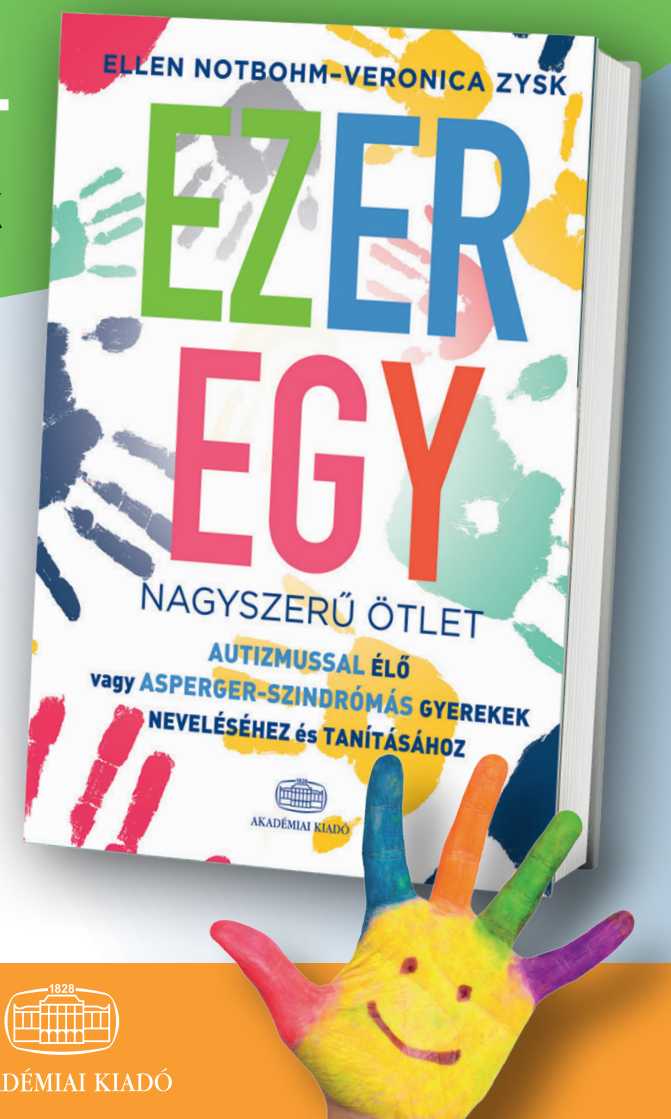

